Jurnal J-Ensitec: Vol 02|No. 02, Mei 2016

\title{
SISTEM PAKAR UNTUK MENGIDENTIFIKASI MASALAH PSIKOLOGI REMAJA MENGGUNAKAN METODE INFERENSI FORWARD CHAINING BERBASIS ANDROID
}

\author{
Tantri Wahyuni \\ Teknik Informatika, Fakultas Teknik Universitas Majalengka \\ email: Tantri_wahyuni80@yahoo.co.id
}

\begin{abstract}
Abstrak
Perkembangan Telepon seluler pada saat ini sudah mengalami kemajuan yang sangat pesat. Dengan menggunakan Metode Inferensi Forward Chaining berbasis android, setiap orang tua dapat mengetahui masalah apa yang sedang terjadi dengan anaknya, khususnya yang berusia remaja. Teknologi ini menggunakan sistem, sehingga membuat suatu keputus andan mengambil keputusan dari sejumlah fakta yang ada. Sistem Pakar ini menggunakan WML dan PHP pada perangkat mobile, melaksanakan tahapan-tahapan yaitu: pengumpulan data dan analisa masalah psikologi remaja menjadi tree, analisa dan perancangan sistem yang berorientasi objek, implementasi berupa percoba anak sistem melalui emulator dan perangkat mobile, serta penarikan kesimpulan dan kegunaan dari sistem pakar yang diterapkan. Fasilitas yang ditawarkan pada sistem pakar ini untuk user umum dan administrator, sehingga sistem bias digunakan oleh sistem dan administrator sesuai dengan hak akses dan kebutuhannya masing- masing. User diberikan informasi mengenai berbagai gejala kenakalan remaja, menuntut user untuk menjawab pertanyaan- pertanyaan sistem untuk mengetahui hasil diagnosa. Sedangkan administrator dimudahkan dalam memanajemen sistem, baik proses tambah, hapus maupun update data terbaru.
\end{abstract}

Kata Kunci : Perangkat mobile, Sistem Pakar, Forward Chaining

\section{PENDAHULUAN}

Perkembangan telepon selular (hand phone) pada zaman sekarang sudah mengalami kemajuan yang sangat pesat. Dengan adanya teknologi android, pengguna selular dapat men-download aplikasi android untuk digunakan pada telepon selularnya.Salah satu yang dapat diterapkan dalam aplikasi andorid yaitu masalahpsikologi remaja. Sistem pakar merupakan salah satu cabang kecerdasan buatan yang mempelajari bagaimana "mengadopsi" cara seorang pakar berfikir dan bernalar dalam menyelesaikan suatu permasalahan dan membuat suatu keputusan maupun mengambil kesimpulan dari sejumlah fakta yang ada.

\section{LANDASAN TEORI}

\subsection{Metode Forward Chaining}

Metode Forward Chaining adalah teknik pelacakan kedepan yang dimulai dengan informasi yang ada dan penggabungan rule untuk menghasilkan suatu kesimpulan atau tujuan. (RusselS, Norvig P, 2003). Berikut adalah diagram

\subsection{StrukturSistemPakar}

Forward Chaining secara umum untuk menghasilkan sebuah goal. Proses penalaran forward chaining terlihat pada gambar dibawah :

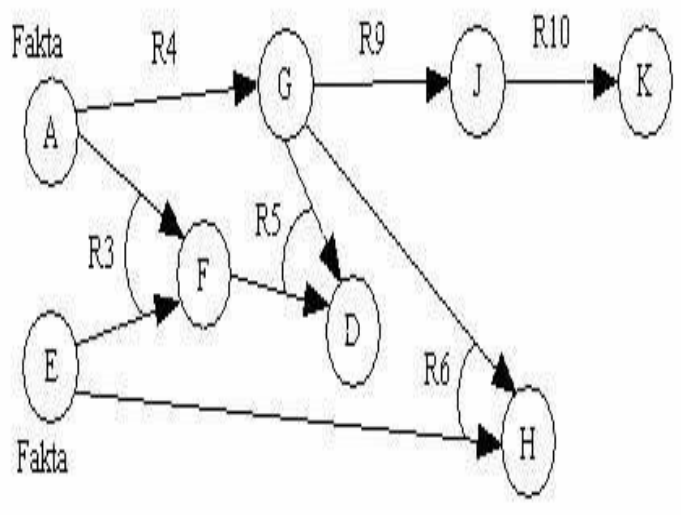

Gambar 1. Skema Proses Forward Chaining (Prof. Dr. Ir. Marimin, MSc:12) 


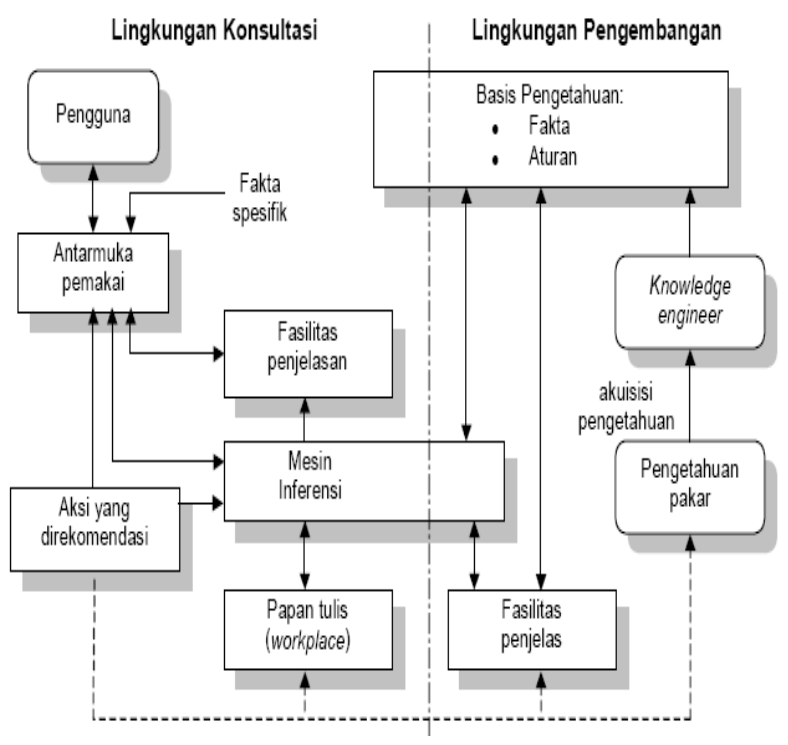

Gambar 2. Struktur Skematis Sebuah Sistem Pakar (Arhami, 2005 : 14)

\section{METODE PENELITIAN}

\subsection{ANALISIS SISTEM}

\section{1.a.Kebutuhan Perangkat Lunak}

Kebutuhan perangkat lunak bahasa pemrograman antarmuka eksternal menggunakan eclipse. Sedangkan untuk kebutuhan fungsional dideskripsikan dalam bentuk tabel sebagai berikut:

Tabel 1 Kebutuhan Fungsional User (Pengguna)

\begin{tabular}{|c|c|}
\hline No & Deskripsi Kebutuhan \\
\hline 1 & Mengecek Data Masalah \\
\hline 2 & Memilih Data Masalah \\
\hline
\end{tabular}

Tabel 2 Kebutuhan Fungsional Pakar

\begin{tabular}{|c|c|}
\hline No & Deskripsi Kebutuhan \\
\hline 1 & Mencatat Data Solusi \\
\hline 2 & Menampilkan Data Solusi \\
\hline
\end{tabular}

3.1.b. Hasil Analisis Kebutuhan End User (Pengguna Akhir) Tentang Sistem Pakar Diperoleh dengan melakukan interview dengan beberapa remaja di Kabupaten Majalengka. Hasil analisisnya sebagai berikut :

1. Sistem pakar yang dirancang harus mampu memberikan solusi untuk beberapa masalah psikologi pada remaja.

2. Sistem yang dirancang harus memberikan tampilan (interface) dan proses-proses yang mudah untuk dioperasikan bahkan bila dioperasikan oleh orang yang awam tentang komputer sekalipun.

3. Sistem harus mampu memberikan solusi dengan cepat mengenai masalah psikologi pada remaja 


\section{1.c. Tabel Keputusan}

\section{Tabel 3. Keputusan Remaja Bermasalah}

\begin{tabular}{|c|c|c|c|c|c|c|c|c|c|c|c|}
\hline No & Ciri-ciri & $\mathbf{a}$ & $\mathbf{b}$ & $\mathbf{c}$ & d & $\mathbf{e}$ & f & $\mathbf{g}$ & $\mathbf{h}$ & $\mathbf{i}$ & $\mathbf{j}$ \\
\hline 1 & $\begin{array}{l}\text { Tidak mau bertemu dengan teman sebaya, mengalami kesulitan } \\
\text { untuk bermain dengan tenang }\end{array}$ & $*$ & $*$ & $*$ & $*$ & $*$ & $*$ & & & & \\
\hline 2 & Sulit berpikir dan memusatkan perhatian & $*$ & $*$ & $*$ & $*$ & & & & & & \\
\hline 3 & Lesu dan tak bertenaga & $*$ & $*$ & * & & & & & & & \\
\hline 4 & Berperilaku lamban, suka menyerang, bahkan gelisah & $*$ & $*$ & & & $*$ & & & & & \\
\hline 5 & Rasa bersalah yang tidak pada tempatnya & $*$ & & & & & & $*$ & & & \\
\hline 6 & Tidak mampu konsentrasi & $*$ & & & $*$ & & & $*$ & & & \\
\hline No & Ciri-ciri & $\mathbf{a}$ & $\mathbf{b}$ & $\mathbf{c}$ & $\mathbf{d}$ & e & $\mathbf{f}$ & $\mathbf{g}$ & $\mathbf{h}$ & $\mathbf{i}$ & $\mathbf{j}$ \\
\hline 7 & Menarik diri dari lingkungan & $*$ & $*$ & & & & $*$ & $*$ & & & \\
\hline 8 & Kurang memiliki motivasi & $*$ & $*$ & & & & & $*$ & $*$ & & \\
\hline 9 & Sering lupa menyelesaikan tugas & $*$ & $*$ & & $*$ & & & & & & \\
\hline 10 & Remaja sering marah dan rewel & $*$ & $*$ & & & & & & & & \\
\hline 11 & $\begin{array}{l}\text { Kehilangan minat dan segala, aktivitas, hobi dan kegiatan yang } \\
\text { sebelumnya disenangi }\end{array}$ & $*$ & $*$ & & & & & $*$ & & & \\
\hline 12 & Malas belajar & $*$ & & & $*$ & & & & * & & \\
\hline 13 & $\begin{array}{l}\text { Mengalami kesulitan dalam mempertahankan perhatian ketika } \\
\text { sedang melakukan aktivitas belajar atau bermain }\end{array}$ & $*$ & * & & $*$ & & & & $*$ & & \\
\hline 14 & Menjadi sangat sensitif & $*$ & $*$ & & & & & $*$ & & & \\
\hline 15 & $\begin{array}{l}\text { Melakukan permainan yang melibatkan kekerasan baik terhadap diri } \\
\text { sendiri atau orang lain }\end{array}$ & $*$ & & & & & & & & & \\
\hline 16 & Perasaan sedih terus menerus & $*$ & $*$ & & & & & $*$ & & * & \\
\hline 17 & Perubahan nafsu makan dan berat badan yang menyolok & $*$ & $*$ & & & & & & & & $*$ \\
\hline 18 & Sering meninggalkan tempat duduk saat mengikuti kegiatan di kelas & & & & $*$ & $*$ & & & & & \\
\hline 19 & Mengalami kesulitan dalam mengikuti petunjuk orang lain & & $*$ & & $*$ & & & & & & \\
\hline 20 & $\begin{array}{l}\text { Seringkali meninggalkan kegiatan yang belum tuntas dan beralih } \\
\text { pada kegiatan baru }\end{array}$ & & & & $*$ & & & & & & \\
\hline 21 & Seringkali menyela percakapan atau mengganggu orang lain & & & & $*$ & $*$ & & & & & \\
\hline 22 & Seringkali tidak mendengar apa yang telah dikatakan kepadanya & & & & $*$ & & & & & & \\
\hline 23 & $\begin{array}{l}\text { Seringkali kehilangan benda-benda yang diperlukan dalam kegiatan } \\
\text { belajarnya di sekolah maupun di rumah }\end{array}$ & & & & $*$ & & & & & & \\
\hline 24 & Tidak mampu memberikan perhatian terhadap hal-hal yang kecil & & $*$ & & $*$ & $*$ & & & & & \\
\hline 25 & $\begin{array}{l}\text { Tidak mampu memusatkan perhatian secara terus-menerus pada saat } \\
\text { menyelesaikan tugas/bermain }\end{array}$ & & & & * & & & & $*$ & & \\
\hline No & Ciri-ciri & $\mathbf{A}$ & $\mathbf{B}$ & $\mathbf{C}$ & $\mathbf{D}$ & $\mathbf{E}$ & $\mathbf{F}$ & $\mathbf{G}$ & $\mathbf{H}$ & $\mathbf{I}$ & $\mathbf{J}$ \\
\hline 26 & $\begin{array}{l}\text { Sering membuat kesalahan yang sesungguhnya tidak perlu terjadi } \\
\text { saat mengerjakan tugas di sekolah }\end{array}$ & & & & $*$ & & & & & $*$ & \\
\hline 27 & Sering berperilaku seperti mengendarai motor & & & & & $*$ & & & & & \\
\hline 28 & Tidak mampu menjalin interaksi sosial yang cukup memadai & & $*$ & & & & $*$ & & & & \\
\hline 29 & Tidak dapat empati & & & & & & * & & & & \\
\hline 30 & Perkembangan bicara terlambat atau sama sekali tidak berkembang & & & & & & $*$ & & & & \\
\hline 31 & Kurang dalam berhubungan dengan orang lain & & $*$ & & & & $*$ & $*$ & & & \\
\hline 32 & Kurang ekspresif serta kurang beremosi & & & & & & $*$ & & & & \\
\hline 33 & Cara bermain kurang variatif, imajinatif dan kurang dapat meniru & & & & & & $*$ & & & & \\
\hline 34 & Sering menggunakan bahasa yang aneh dan berulang-ulang & & & & & & $*$ & & & & \\
\hline 35 & $\begin{array}{l}\text { Mempertahankan satu minat/lebih dengan cara yang sangat khas dan } \\
\text { berlebihan }\end{array}$ & & & & & & $*$ & & & & \\
\hline 36 & Jumlah kosa kata yang dikuasai sangat minim dan tidak sesuai & & & & & & $*$ & & $*$ & & \\
\hline
\end{tabular}




\begin{tabular}{|c|c|c|c|c|c|c|c|c|c|c|c|}
\hline & dengan usianya & & & & & & & & & & \\
\hline 37 & Kurang berinisiatif dalam berkomunikasi dengan orang lain & & $*$ & & & & $*$ & & & & \\
\hline 38 & Remaja memperlihatkan ketakutan yang berlebihan & & $*$ & $*$ & & & & & & & \\
\hline 39 & Tidak lari ke orang tua untuk meminta dukungan & & & $*$ & & & & & & & \\
\hline 40 & Memperlihatkan tingkah laku yang agresif & & * & $*$ & & & & & & & \\
\hline 41 & Tidak penurut & & & $*$ & & & & & & & \\
\hline 42 & Memuntahkan makanan & & & & & & & & & & $*$ \\
\hline 43 & Makan berlama-lama dan memainkan makanan & & & & & & & & & & $*$ \\
\hline 44 & Sama sekali tidak mau makan & & & & & & & & & & $*$ \\
\hline 45 & Menumpahkan makanan & & & & & & & & & & $*$ \\
\hline 46 & Menepis suapan dari orang tua & & & & & & & & & & $*$ \\
\hline 47 & Sulit mengeja dengan benar & & & & & & & & * & & \\
\hline 48 & Sulit mengeja dengan kata & & & & $*$ & & & & * & & \\
\hline 49 & $\begin{array}{l}\text { Ketika sedang membaca sering salah melanjutkan ke paragraf } \\
\text { berikutnya atau tidak berurutan }\end{array}$ & & & & & & & & $*$ & & \\
\hline No & Ciri-ciri & $\mathbf{A}$ & B & $\mathbf{C}$ & $\mathbf{D}$ & $\mathbf{E}$ & $\mathbf{F}$ & $\mathbf{G}$ & $\mathbf{H}$ & I & $\mathbf{J}$ \\
\hline 50 & Kesulitan mengurutkan huruf-huruf dalam kata & & & & & & & & $*$ & & \\
\hline 51 & Kesalahan mengeja yang dilakukan secara terus-memerus & & & & & & & & $*$ & & \\
\hline 52 & Sulit memegang alat tulis dengan mantap & & & & & & & & $*$ & & \\
\hline 53 & Sering salah menulis kata-kata & & & & & & & & $*$ & & \\
\hline 54 & Terlalu memfokuskan pada tangan ketika menulis & & & & & & & & $*$ & & \\
\hline 55 & Sulit melakukan hitungan matematis & & & & & & & & $*$ & & \\
\hline 56 & Menyendiri, pendiam dan tidak ceria lagi & & $*$ & $*$ & & & & $*$ & & $*$ & \\
\hline 57 & Enggan pergi ke tempat tertentu & & $*$ & $*$ & & & & $*$ & & $*$ & \\
\hline 58 & Menjelaskan aktivitas seksual dengan bahasa mereka sendiri & & & & & & & $*$ & & $*$ & \\
\hline 59 & $\begin{array}{l}\text { Menunjukan perilaku yang merusak diri sendiri seperti pergi dari } \\
\text { rumah }\end{array}$ & & & & & & & $*$ & & $*$ & \\
\hline
\end{tabular}

\section{Keterangan :}

Pada baris menunjukan ciri-ciri yang ditimbulkan oleh remaja bermasalah, sedangkan pada kolom merupakan nama-nama remaja bermasalah. Keterangannya adalah sebagai berikut :
a. Depresi
b. Kecemasan dan Menarik Diri dari Sosial
c. Kekerasan pada Remaja
d. Gangguan Pemusatan Perhatian
e. Hiperaktivitas
f. Autisme dan Redartasi Mental
g. Kekerasan Seksual pada Remaja
h. Gangguan Belajar
i. Konflik Keluarga
j. Gangguan Pola Makan

\section{1.d. Pohon Keputusan}

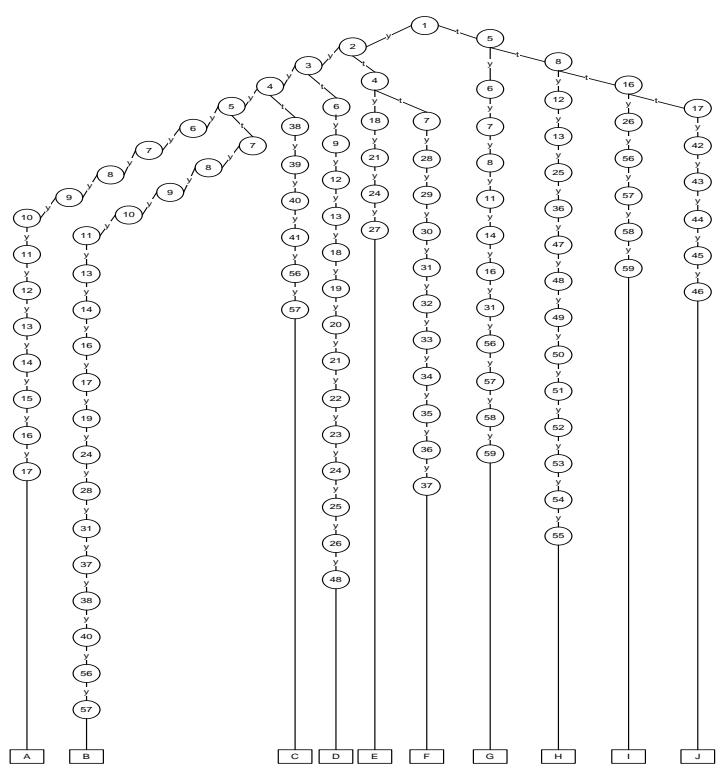

Gambar 3.PohonKeputusan 


\subsection{PERANCANGAN SISTEM}

\section{2.a.Diagram Kelas}

Diagram

kelas

menggambarkan

keterkaitan antar kelas dan mempresentasikan struktur dari sistem.

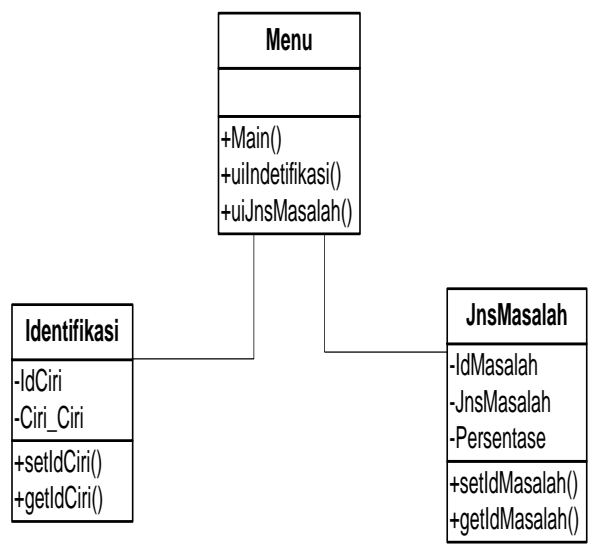

Gambar 4. Diagram Kelas

\section{Keterangan:}

\begin{tabular}{|l|l|l|l|}
\hline \multicolumn{1}{|c|}{ No } & \multicolumn{1}{c|}{ Class } & \multicolumn{1}{c|}{ Artibut } & \multicolumn{1}{c|}{ Method } \\
\hline 1 & Menu & - & $\begin{array}{l}\text { main, } \\
\text { uiIndetifikasi, dan } \\
\text { uiJnsMasalah }\end{array}$ \\
\hline 2 & $\begin{array}{l}\text { Identifik } \\
\text { asi }\end{array}$ & $\begin{array}{l}\text { IdCiri, dan } \\
\text { Ciri-ciri }\end{array}$ & $\begin{array}{l}\text { setIdCiri, dan } \\
\text { getIdCiri }\end{array}$ \\
\hline 3 & $\begin{array}{l}\text { JnsMasa } \\
\text { lah }\end{array}$ & $\begin{array}{l}\text { IdMasalah,J } \\
\text { nsMasalah, } \\
\text { dan } \\
\text { Presentase }\end{array}$ & $\begin{array}{l}\text { setIdMasalah, dan } \\
\text { getIdMasalah }\end{array}$ \\
\hline
\end{tabular}

\section{2.b.Diagram State}

Berikut adalah diagram state dari sistem :

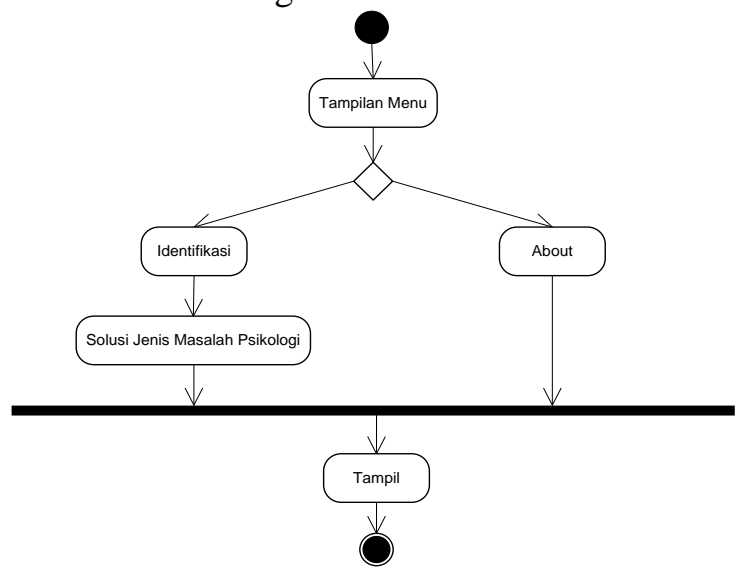

\section{Keterangan:}

Gambar di atas menggambarkan tentang alur jalanya sebuah aplikasi yang sedang di buat, dari Tampilan Menu di bagi menjadi 2 arah yaitu identifikasi dan about. Jika user memilih identifikasi maka akan muncul solusi jenis masalah pisikologi, lalu tampil solusi yang di cari.

\section{2.c.Diagram Sequence}

\section{Operator (Pencarian Solusi)}

a. Cek data masalah

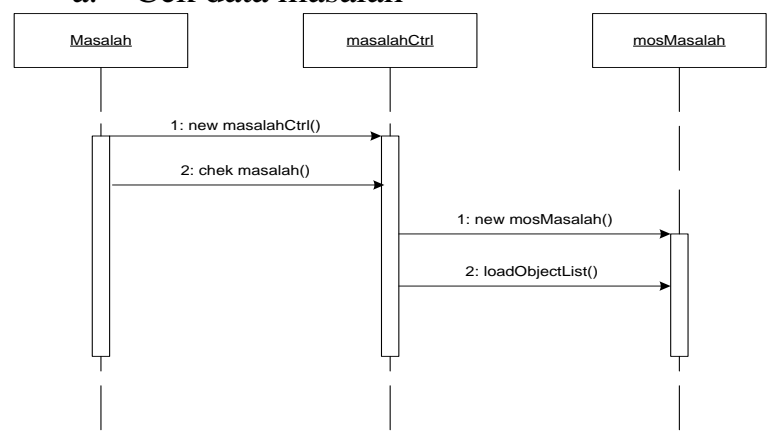

Gambar 6. Diagram Sequence Cek data masalah

\section{Keterangan:}

Gambar di atas mengambarkan tentang Cek data masalah, dengan proses masalah baru, dan di chek masalah. proses penyimpanannya masalah baru lalu di tampilkan object list.

b. Pilih data masalah

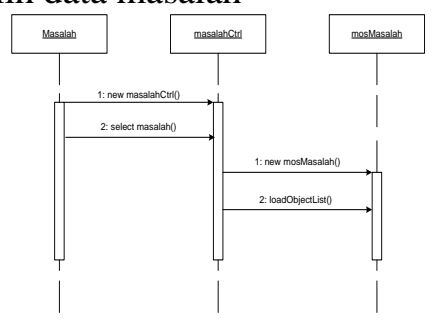

Gambar 7.Diagram Sequence Pilih data masalah

\section{Keterangan:}

Gambar di atas mengambarkan tentang Pilih data masalah, dengan proses masalah baru, dan memilih masalah. proses penyimpanannya masalah baru lalu di tampilkan object list.

Gambar 5. Diagram State 


\section{Pakar (Penyampaian Solusi)}

a. Catat data solusi

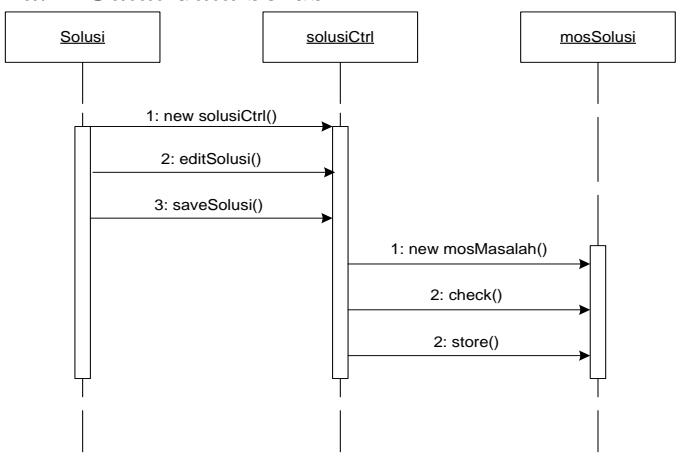

Gambar 8. Diagram Sequence Catat data solusi

\section{Keterangan:}

Gambar di atas mengambarkan tentang Catat data solusi, dengan proses solusi baru lalu edit solusi dan menyimpan solusi, proses penyimpanannya solusi baru lalu di tampilkan object list.

b. Tampilkan data solusi

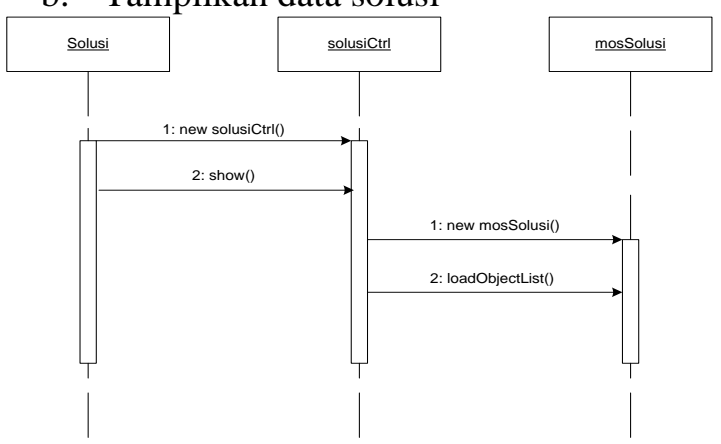

Gambar 9. Diagram Sequence Tampilkan data solusi

\section{Keterangan:}

Gambar di atas mengambarkan tentang Tampilkan data solusi, dengan proses solusi baru lalu menampilkan solusi, proses penyimpanannya solusi baru lalu menampilkan object list.

\section{2.d.Diagram Deployment}

Diagram deployment menggambarkan arsitektur fisik dari sistem, seperti hardware.

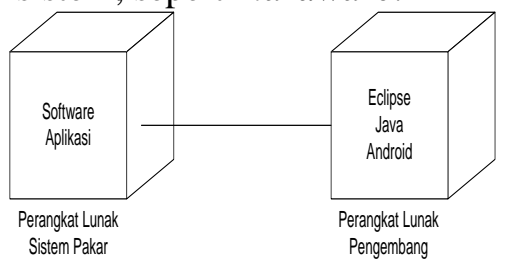

Gambar 10. Diagram Deployment

\section{2.e.Diagram Package}

Dalam perkembangannya perangkat lunak sistem pakar ini memiliki banyak kelas, sehingga pengelompokkan kelas-kelas tersebut menjadi sangat membantu pencarian sebuah kelas baik dari level yang lebih tinggi maupun menuju level yang lebih detail.

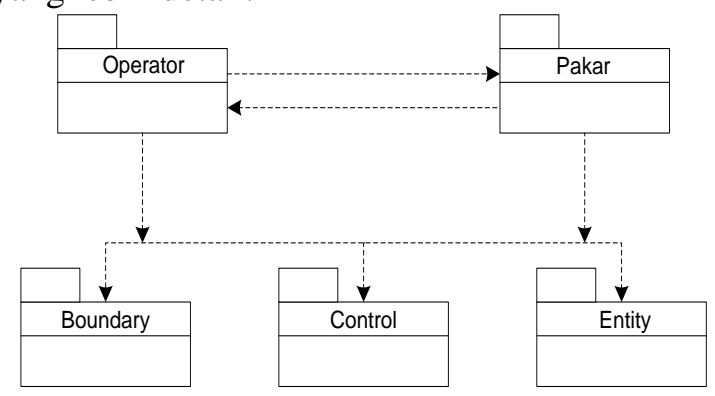

Gambar 11. Diagram Package

\section{2.f.Diagram Komponen}

Diagram komponen menggambarkan paket fisik dari modul pengkodean dan menunujukkan interface yang digunakan untuk berkomunikasi antar komponen.

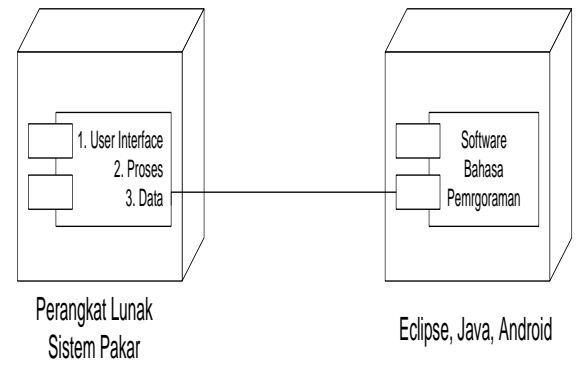

Gambar 12. Diagram Komponen

\section{2.g.Rancangan Tampilan Program}

Adapun rancangan tampilan dari aplikasi yang penulis buat adalah sebagai berikut.

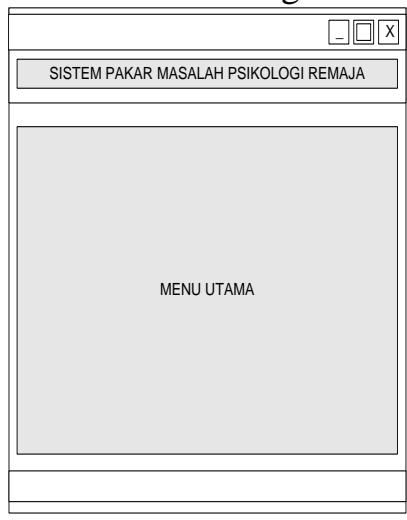

Gambar 13.RancanganTampilan Menu Utama 


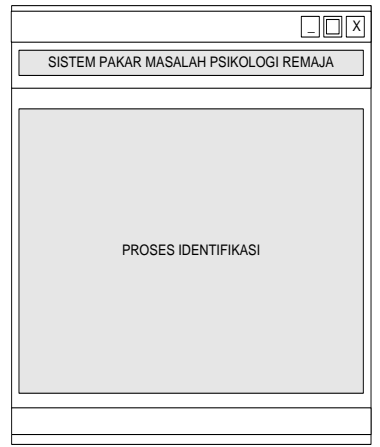

Gambar 14. Rancangan Tampilan Proses

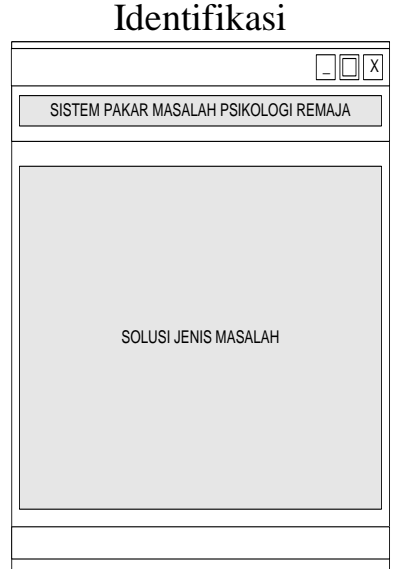

Gambar 15. Rancangan Tampilan Solusi

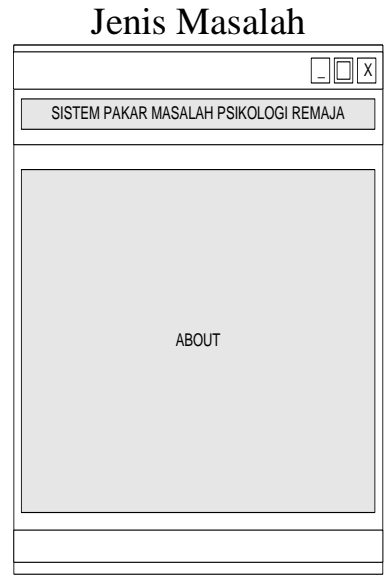

Gambar 16. Rancangan Tampilan About

\section{KESIMPULAN DAN SARAN}

\subsection{Kesimpulan}

Kesimpulan yang dapat diambil dari penelitian ini adalah:

1. Sistem pakar untuk mengidentifikasi masalah psikologi remaja dapat digunakan untuk mengidentifikasi masalah berdasar kan ciriciri yang dirasakan user, sehingga user menemukan solusi atas permasalahan yang dihadapi.
2. Dampak negatif dari perkembangan remaja yang kurang perhatian dari orangtuanya dapat dijadikan perhatian khusus bagi orang tua, sehingga para orangtua dapat menggunakan sistem pakar ini untuk mengidentifikasi masalahyang terjadi pada anaknya dan menemukan solusi dari sistem ini.

3. Sistem pakar ini dirancang agar dapat menangani masalah psikologi remaja bukan hanya memberikan solusi tetapi juga bermanfaat bagi orang lain.

\subsection{Saran}

Saran-saran yang dapat diberikan terhadap jalannya sistem pakar untuk mengidentifikasi masalah psikologi remaja adalah:

1. Untuk menjalankan aplikasi ini perlu perangkat mobile yang berbasis android.

2. Untuk kedepannya sistem pakar ini perlu dilakukan penambahan data pengetahuan (update knowledge base) oleh pakar sehingga cakupan data dan solusinya menjadi lebih kompleks.

V. DAFTAR PUSTAKA

Arhami, Muhammad. 2005. Konsep Dasar Sistem Pakar. Yogyakarta : ANDI.

A.S., Rosa, M. Shalahuddin. 2011. Modul Pembelajaran Rekayasa Perangkat Lunak (Terstruktur dan Berorientasi Objek). Bandung : MODULA.

B,Al-Bahra bin Ladjamuddin. 2004. Konsep Sistem BasisData dan Implementasinya. Yogyakarta : GRAHA ILMU.

Dharwiyanti, SridanRomiSatriaWahono. 2003. Pengantar Unified Modeling Language (UML). IlmuKomputer.Com

Hartati Sri, Sari Iswanti. 2008. Sistem Pakar \& Pengembangannya. Yogyakarta : Graha Ilmu.

Maria Polina, S.Kom., M.Sc., Agnes, Drs. Jong Jek Siang, M.Sc. 2005 Kiat Jitu Menyusun Skripsi Jurusan Informatika / Komputer. Yogyakarta: ANDI OFFSET.

Safaat H., Nazruddin. 2014. AndroidPemrograman Aplikasi Mobile Smartphone dan Tablet PC Berbasis Andorid. Bandung : INFORMATIKA. 